\title{
Simian Immunodeficiency Virus (SIV)-Specific Chimeric Antigen Receptor-T Cells Engineered to Target B Cell Follicles and Suppress SIV Replication
}

\author{
Kumudhini Preethi Haran', Agnes Hajduczki ${ }^{2}$, Mary S. Pampusch', Gwantwa \\ Mwakalundwa ${ }^{1}$, Diego A. Vargas-Inchaustegui ${ }^{2}$, Eva G. Rakasz ${ }^{3}$, Elizabeth Connick ${ }^{4}$, \\ Edward A. Berger ${ }^{2 *}$ and Pamela J. Skinner ${ }^{1 *}$ \\ ${ }^{1}$ Department of Veterinary and Biomedical Sciences, University of Minnesota, St. Paul, MN, United States, ${ }^{2}$ Laboratory of \\ Viral Diseases, National Institute of Allergy and Infectious Diseases, National Institutes of Health, Bethesda, MD, \\ United States, ${ }^{3}$ Wisconsin National Primate Research Center, University of Wisconsin-Madison, Madison, WI, United States, \\ ${ }^{4}$ Division of Infectious Diseases, University of Arizona, Tucson, AZ, United States
}

\section{OPEN ACCESS}

Edited by:

Vijayakumar Velu,

Emory University, United States

Reviewed by:

Afam Okoye,

Oregon Health \& Science

University, United States

Marie Larsson,

Linköping University, Sweden

${ }^{*}$ Correspondence:

Edward A. Berger eberger@niaid.nih.gov;

Pamela J. Skinner

skinn002@umn.edu

Specialty section:

This article was submitted

to Viral Immunology,

a section of the journal

Frontiers in Immunology

Received: 30 November 2017

Accepted: 26 February 2018

Published: 20 March 2018

Citation:

Haran KP, Hajduczki A,

Pampusch MS, Mwakalundwa G, Vargas-Inchaustegui $D A$, Rakasz EG, Connick E, Berger EA and Skinner PJ

(2018) Simian Immunodeficiency Virus (SIV)-Specific Chimeric Antigen

Receptor-T Cells Engineered to Target B Cell Follicles and Suppress

SIV Replication.

Front. Immunol. 9:492.

doi: 10.3389/fimmu.2018.00492
There is a need to develop improved methods to treat and potentially cure HIV infection. During chronic HIV infection, replication is concentrated within T follicular helper cells (Tfh) located within B cell follicles, where low levels of virus-specific CTL permit ongoing viral replication. We previously showed that elevated levels of simian immunodeficiency virus (SIV)-specific CTL in B cell follicles are linked to both decreased levels of viral replication in follicles and decreased plasma viral loads. These findings provide the rationale to develop a strategy for targeting follicular viral-producing (Tfh) cells using antiviral chimeric antigen receptor (CAR) T cells co-expressing the follicular homing chemokine receptor CXCR5. We hypothesize that antiviral CAR/CXCR5-expressing T cells, when infused into an SIV-infected animal or an HIV-infected individual, will home to B cell follicles, suppress viral replication, and lead to long-term durable remission of SIV and HIV. To begin to test this hypothesis, we engineered gammaretroviral transduction vectors for co-expression of a bispecific anti-SIV CAR and rhesus macaque CXCR5. Viral suppression by CAR/ CXCR5-transduced T cells was measured in vitro, and CXCR5-mediated migration was evaluated using both an in vitro transwell migration assay, as well as a novel ex vivo tissue migration assay. The functionality of the CAR/CXCR5 T cells was demonstrated through their potent suppression of $\mathrm{SIV}_{\text {mac239 }}$ and $\mathrm{SIV}_{\mathrm{E} 660}$ replication in in vitro and migration to the ligand CXCL13 in vitro, and concentration in B cell follicles in tissues ex vivo. These novel antiviral immunotherapy products have the potential to provide long-term durable remission (functional cure) of HIV and SIV infections.

Keywords: HIV, simian immunodeficiency virus, chimeric antigen receptor, CAR-T cells, CXCR5, B cell follicles, CD8 $^{+} \mathbf{T}$ cells, HIV cure strategies

\section{INTRODUCTION}

Over 2 million individuals become infected with HIV each year, and nearly 37 million people are currently infected with HIV (1). Current antiretroviral therapy (ART), while effective at reducing viral loads, does not eliminate the virus, thus requiring HIV-infected individuals to remain on ART for life. ART is expensive, inconvenient, demands strict adherence, and, in some cases, leads to 
drug resistance. In addition, $\mathrm{HIV}$-infected individuals remain at increased risk of cardiovascular disease (2), neurological disease (3), and malignancies (4), and have decreased life expectancies (5). Given these issues and risks, there is great global interest in developing strategies to fully eradicate infectious HIV from the body ("sterilizing cure"), or to achieve durable viral remission in the absence of ART ("functional cure") (6).

During chronic HIV and simian immunodeficiency virus (SIV) infections prior to the development of AIDS, virus replication is most concentrated within B cell follicles (7-12), primarily within T follicular helper cells (Tfh) $(10,13,14)$. Replication is further sustained by infectious virions adhering to the surface of follicular dendritic cells (FDC) via antibody and complement complexes in germinal centers (15-19). Although virus-specific $\mathrm{CD}^{+} \mathrm{T}$ cells are critical for controlling HIV and SIV infections, they fail to fully suppress viral replication (20). Several mechanisms are thought to contribute to this failure including: the emergence of CTL escape variants (21-28), viral induced MHC class I down-modulation (29, 30), viral latency (31), CTL exhaustion (32-34), and potential Treg inhibition of CTL (35-39). A particularly compelling factor, which we address in this study, is that levels of virus-specific CD ${ }^{+} \mathrm{T}$ cells are low within B cell follicles, thereby permitting ongoing viral replication (8, 9, 40-42).

Migration of cells into the B cell follicle is mediated through the chemokine receptor, CXCR5 (43-45), and its ligand, the chemokine CXCL13 (46, 47), which is expressed by B cells (48-50) and FDCs in follicles $(47,51)$. We hypothesize that increasing levels of virus-specific CTL in B cell follicles will lead to significantly better control of viral replication in B cell follicles and might lead to sustained remission of HIV infection (42). Several lines of evidence support this hypothesis. In lymphocytic choriomeningitis virus (LCMV)-infected mouse models, adoptive transfer of CXCR5-expressing, LCMV-specific CD8 ${ }^{+} \mathrm{T}$ cells controlled LCMV infection of Tfh cells and reduced viral loads significantly better than $\mathrm{CXCR}^{-} \mathrm{CD}^{+} \mathrm{T}$ cells $(52,53)$. We previously showed that levels of SIV-specific CTL in lymphoid compartments predicted levels of viral replication in lymphoid compartments (8) and that levels of SIV-specific CTL in follicles tended to predict plasma viral loads (36). Furthermore, it was reported recently that levels of virus-specific CXCR5 $5^{+}$cells inversely correlated with viral load in HIV-infected individuals (52). In addition, in a recent SIV CTL vaccine study, it was found that vaccine induced protection from pathogenic SIV challenge was associated with increased levels of $\mathrm{CXCR}^{+}$virus-specific $\mathrm{CD}^{+} \mathrm{T}$ cells (54). Thus, increasing virus-specific $\mathrm{CD}^{+} \mathrm{T}$ cells in $\mathrm{B}$ cell follicles is predicted to lead to better control of viral replication in lymphoid follicles and decreased viral loads.

In the field of cancer immunotherapy, dramatic successes have been achieved by genetically engineering autologous patient $\mathrm{T}$ cells to express a chimeric antigen receptor (CAR). CAR-T cells have shown great promise in treating certain $\mathrm{B}$ cell leukemias and lymphomas, and are being actively pursued to treat additional cancers including solid tumors (55-57). Several features make CAR technology particularly appealing in HIV functional cure efforts (58-61). CAR activity is MHC-independent, and thus not compromised by HIV-1 nef-mediated down-modulation of MHC-I in infected cells that facilitates their evasion from conventional cytotoxic T cells (62). The target for an anti-HIV CAR is the viral Env glycoprotein, which is expressed exclusively on infected cells. Env is absolutely essential for virus infectivity and spread, and the targeting motif of the CAR can be designed to recognize strictly conserved Env elements that are refractory to mutational escape. Interestingly, the very first clinical tests of CAR technology were directed against HIV-1 infection, using first-generation CAR constructs employing CD4 as the targeting motif; while minimal virus suppression was achieved, the gammaretroviral-engineered CAR-T were found to be safe, and had stable levels of engraftment with a decay half-life exceeding 16 years (63-66).

Achieving durable HIV/SIV remission in the absence of ART demands long-term persistence of functional CAR-T cells, with minimal chance for virus mutational escape and immune response against the CAR. To this end, we have designed bispecific CARs containing CD4 (domains 1 and 2) linked to a second moiety that binds to a distinct highly conserved site on the HIV-1 Env glycoprotein. The second moiety both enhances CAR potency and prevents the CD4 from acting as an entry receptor in CAR-expressing CD8 ${ }^{+} \mathrm{T}$ cells $(67,68)$. In a favored CAR construct (68), the second moiety is the carbohydrate recognition domain of mannose-binding lectin (MBL), which binds to the dense oligomannose patch that is highly conserved on clinically relevant HIV-1 variants. Indeed, compared to a monospecific CD4 CAR, the CD4-MBL CAR displays superior suppressive activity against genetically diverse $\mathrm{HIV}-1$ primary isolates. Immunogenicity concerns are minimized with the CD4-MBL CAR, since both Env-binding components are derived entirely from human protein sequences; moreover, the MBL moiety lacks the equivalent of variable regions that are likely to elicit immune responses during the long-term persistence required to durably maintain HIV suppression.

In the present study, we address another major concern for achieving effective HIV control, namely the likely requirement to enhance CAR-T cell trafficking to B cell follicles. To this end, we engineered rhesus macaque $\mathrm{T}$ cells to co-express CXCR5 along with an all-rhesus variant of the CD4-MBL CAR. Results from in vitro and ex vivo assay systems suggest promising potential of this approach as a means to direct CAR-T cells to B cell follicles, where HIV replication is concentrated.

\section{MATERIALS AND METHODS}

\section{Plasmid Constructs and Retroviral Vectors Encoding CARs}

All CAR targeting motifs were synthesized by GenScript, codon-optimized for expression in rhesus macaque cells, and subcloned into the plasmid pMSGV1 gammaretrovirus vector backbone (69). The active antiviral CAR employed in this study was a rhesus variant of the human bispecific CAR designated CD4-MBL (68). As a non-reactive negative control, we used the previously described $139 \mathrm{CAR}$, which does not react with cells in this system. The targeting domains were linked to extracellular hinge, transmembrane and cytoplasmic co-stimulatory domain of rhesus CD8 followed by the activation domain of rhesus CD3 zeta, as previously described $(67,68)$. 
$\mathrm{T}$ cells were transduced to express either the rhCD4-MBL CAR, rhCXCR5, or the rhCD4-MBL CAR plus rhCXCR5. For co-expression, bicistronic plasmid constructs (produced by GenScript) were designed in which the rhCD4-MBL gene was linked to the downstream rhCXCR5 gene. CXCR5 expression was driven by either the ECMV internal ribosome entry site (IRES) or the self-cleaving P2A peptide from porcine teschovirus-1 with a GSG linker added at the N-terminus of the P2A peptide sequence (70). The corresponding gammaretroviruses were generated for expression of these genes in rhesus macaque $\mathrm{T}$ cells. In most experiments, these plasmids were co-transfected with the plasmid pBS-CMV-gagpol (71) (a gift from Dr. Patrick Salmon, Addgene plasmid \#35614), a plasmid encoding RD114 envelope glycoprotein (72), and the plasmid pMD.G encoding VSV-G envelope (73) (a gift from Dr. Scott McIvor) at ratios of 3:1:1:0.4, respectively. Retroviral vector supernatants were collected $48 \mathrm{~h}$ after transfection, and were titrated by transducing HEK293T cells. Retrovirus was snap frozen and stored at $-80^{\circ} \mathrm{C}$. In the SIV suppression studies, gammaretrovirus vector production was carried out as previously described (67).

\section{Transduction of Rhesus T Cells}

Primary rhesus macaque PBMC, or $\mathrm{CD}^{+} \mathrm{T}$ cells enriched by negative selection (Miltenyi), were activated for 2 to 3 days in six-well plates with plate-bound anti-CD3 (FN18) and soluble anti-CD28.2 (both from NHP Reagent Resource) in either RPMI supplemented with $10 \%$ heat inactivated FBS, $100 \mathrm{U} / \mathrm{ml}$ penicil-

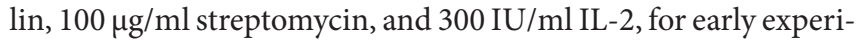
ments, or in X-Vivo 15 completed with $10 \%$ heat inactivated FBS, $100 \mathrm{U} / \mathrm{ml}$ penicillin, $100 \mu \mathrm{g} / \mathrm{ml}$ streptomycin, $2 \mathrm{mM}$ glutamine, and $50 \mathrm{IU} / \mathrm{ml} \mathrm{IL-2} \mathrm{for} \mathrm{later} \mathrm{experiments.} \mathrm{RetroNectin} \mathrm{(TaKaRa)-}$ mediated transduction was carried out on the activated $\mathrm{T}$ cells. Retroviral vector supernatants, diluted in serum-free media, were added (eventual MOI of 0.5 ) to RetroNectin-coated six-well plates and centrifuged for $2 \mathrm{~h}$ at $2,000 \times g$ to facilitate binding of the retrovirus. After removal of the unbound retrovirus, activated PBMC or $\mathrm{CD}^{+} \mathrm{T}$ cells $\left(1.5 \times 10^{6}\right.$ cells/well $)$ were added to the wells and centrifuged at $1,000 \times g$ for $10 \mathrm{~min}$. Mock-transduced cells were subjected to exactly the same procedures without the addition of retrovirus to the RetroNectin-coated wells. Cells were cultivated in the media listed above for 5-6 days prior to analysis by flow cytometry.

\section{Flow Cytometry}

Cells were analyzed using an LSR Fortessa flow cytometer (BD Bioscience). The following antibodies were used: CD4 (M-T477, reactive with endogenous rhCD4 and the rhCD4-MBL CAR), CD3 (SP34-2), CD8 (RPA-T8) (all from BD Bioscience), CXCR5 (MU5UBEE) (eBioscience), MBL2 (3E7) (Invitrogen). Viability was assessed with the Live/Dead Fixable Near IR Dead Cell Stain Kit (Invitrogen). A minimum of 70,000 events were acquired for each sample. Data analysis utilized FlowJo v10 (FlowJo, LLC).

\section{In Vitro Transwell Migration Assay}

Rhesus macaque PBMCs were transduced with the CAR or CAR/CXCR5 vectors, or mock-transduced. Samples were run in duplicate. For each sample, one million cells in $100 \mu \mathrm{l}$ X-Vivo-15 media containing $0.1 \%$ BSA were placed in the upper chamber of a 24-well plate, with a 5.0- $\mu \mathrm{m}$ transwell membrane (Costar). To the lower chamber containing $600 \mu \mathrm{lX}$-Vivo 15 and $0.1 \%$ BSA, either CXCL12 at $1 \mu \mathrm{g} / \mathrm{ml}$ or CXCL13 at $2.5 \mu \mathrm{g} / \mathrm{ml}$ (both from ProSpec) were added. No chemokine was added to control wells. After incubation for $4 \mathrm{~h}$ at $37^{\circ} \mathrm{C}$, cells were collected from the lower chamber, fixed with $1 \%$ paraformaldehyde, and counted on a Cytoflex flow cytometer (Beckman). All samples were normalized with the addition of AccuCheck Counting Beads (Invitrogen). Specific cell migration was determined by first subtracting the number of cells that migrated to media alone from the number of cells that migrated to the chemokine and then dividing by the number of cells added to the upper chamber.

\section{Ex Vivo B Cell Follicle Migration Assay}

Chimeric antigen receptor- and CAR/CXCR5-transduced rhesus $\mathrm{CD} 8^{+} \mathrm{T}$ cells were used in conjunction with fresh lymph node tissue sections from allogeneic rhesus macaques. A gelatin sponge ( $7 \mathrm{~mm}$ Gel foam by Pfizer) was cut to fit and placed into a six-well plate containing 3-4 ml of RPMI with $20 \%$ heat inactivated FBS. The sponge was hydrated for $1 \mathrm{~h}$ at $37^{\circ} \mathrm{C}$. Fresh rhesus macaque lymph nodes, collected at the Wisconsin National Primate Research Center, were shipped in chilled RPMI containing $100 \mu \mathrm{g} / \mathrm{ml}$ heparin overnight on ice blocks. Lymph nodes were cut into $0.5 \mathrm{~cm} \times 0.5 \mathrm{~cm}$ pieces and embedded in $40^{\circ} \mathrm{C}$ PBS-buffered $4 \%$ low-melt agarose and cut into $300-\mu \mathrm{m}$ thick slices using a Compresstome, as we have previously described (74). Tissue sections and associated agarose were laid flat on the hydrated sponge without being submerged. Transduced $\mathrm{CD} 8^{+} \mathrm{T}$ cells were stained with a $5-\mu \mathrm{M}$ solution of Cell Trace Violet Dye (CTV) (Molecular Probes). The dye was added at a $1: 1$ ratio to $1 \times 10^{7}$ cells $/ \mathrm{ml}$ suspended in $\mathrm{PBS} / 10 \% \mathrm{FBS}$, and cells were incubated for $15 \mathrm{~min}$ at $37^{\circ} \mathrm{C}$, followed by two washes with complete RPMI supplemented with $10 \%$ heat inactivated FBS $100 \mathrm{U} / \mathrm{ml}$ penicillin, and $100 \mu \mathrm{g} / \mathrm{ml}$ streptomycin. For each fresh tissue section, one million CTV-stained transduced $\mathrm{CD} 8^{+}$ $\mathrm{T}$ cells were re-suspended in 20-30 $\mu \mathrm{l}$ complete RPMI and were slowly pipetted onto the surface of the tissue. Tissue sections were incubated at $37^{\circ} \mathrm{C}$ for $6 \mathrm{~h}$ followed fixation with $4 \%$ PBS-buffered paraformaldehyde for $2 \mathrm{~h}$ at RT. After fixation, sections were washed with chilled PBS containing $100 \mu \mathrm{g} / \mathrm{ml}$ heparin (PBS-H). Antigen retrieval was carried out by boiling tissues $3 \times$ in $0.01 \mathrm{M}$ urea for $30 \mathrm{~s}$. Tissues were permeabilized and blocked with PBS-H containing $0.3 \%$ Triton $\mathrm{x}-100$ and $2 \%$ normal goat serum for $1 \mathrm{~h}$, then incubated overnight with mouse-anti-human CD20 $(0.19 \mu \mathrm{g} / \mathrm{ml}$, clone L26, Novocastra) to label B cells and rat-antihuman CD3 (2 $\mu \mathrm{g} / \mathrm{ml}, \mathrm{CD} 3-12$, Bio-Rad) to label T cells. After washing with PBS-H, secondary antibody staining was carried out by incubating tissues overnight with goat-anti-mouse-IgG/ Alexa $488(0.75 \mu \mathrm{g} / \mathrm{ml}$ Jackson ImmunoResearch Laboratories) and goat-anti-rat-IgG/Cy5 $(0.3 \mu \mathrm{g} / \mathrm{ml}$, Jackson ImmunoResearch Laboratories). All incubations were done at $4^{\circ} \mathrm{C}$ on a rocking platform. Sections were imaged using a Leica confocal microscope. $512 \times 512$ pixel $z$-series were collected using a step size of $2 \mu \mathrm{m}$ and with collection initiated at least $50 \mu \mathrm{m}$ deep into each section. B cell follicles were identified morphologically as clusters of brightly stained closely aggregated $\mathrm{CD} 20^{+}$cells. Areas 
that showed loosely aggregated B cells that were ambiguous as to whether the area was a follicle were not included. Cell counts were done with individual $z$-scans. The total number of CTV-stained cells was counted inside follicles and the adjacent area outside of the follicles. For each sample, 2-3 tissue sections and a minimum of three follicles (range 3-8) were evaluated.

\section{SIV Suppression Assay}

To generate SIV-infected target cells, rhesus macaque PBMCs were re-suspended at $5 \times 10^{5} / \mathrm{ml}$ in complete medium, transferred to a T25 flask, and incubated at $37^{\circ} \mathrm{C}$ in $5 \% \mathrm{CO}_{2}$ for $2-3$ days. The PBMCs were washed, adjusted to $3 \times 10^{6} / \mathrm{ml}$ in total of $4 \mathrm{ml}$ volume in complete media containing $30 \mathrm{IU} / \mathrm{ml} \mathrm{IL-2,} \mathrm{and}$ incubated with $200-600 \mathrm{TCID}_{50} / \mathrm{ml}$ of virus for $24 \mathrm{~h}$ at $37^{\circ} \mathrm{C}$ in $5 \% \mathrm{CO}_{2}$. Infected cells were washed three times using $20 \mathrm{ml}$ of medium per wash and then re-suspended in complete medium at a density of $1.5 \times 10^{6}$ cells per $\mathrm{ml}$ in 96-well round bottom plates. To generate effector cells, T cells (derived from activated PBMCs) were transduced with the indicated gammaretroviral vectors. In triplicate, $100 \mu \mathrm{l}$ of SIV-infected targets were mixed with $100 \mu \mathrm{l}$ of serially diluted effectors. Cocultures were incubated at $37^{\circ} \mathrm{C}$ in $5 \% \mathrm{CO}_{2}$ for a total of 16 days. On the indicated days, supernatants were collected, and p27 content was determined by ELISA (ABL, Inc.).

\section{Statistical Analysis}

All statistical analyses assumed two-sided tests with $P<0.05$ considered significant. Paired $t$-tests with pooled variance were used to evaluate co-expression levels of the CAR and CXCR5 via IRES versus $\mathrm{P} 2 \mathrm{~A}$ constructs An unpaired $t$-test with pooled variance was used to evaluate groups in the CXCL12 in vitro migration assays while an unpaired Welch's $t$-test of unequal variance was used to evaluate groups in the CXCL13 in vitro migration assays. Paired $t$-tests with pooled variance were used in all statistical analyses in the ex vivo migration assay. The F:EF ratios were log transformed before analysis. Statistical analyses were conducted using GraphPad Prism (Version 6.01; GraphPad Software, Inc., La Jolla, CA, USA).

\section{RESULTS}

The goal of this study was to engineer rhesus macaque $\mathrm{T}$ cells to co-express a potent anti-SIV CAR along with CXCR5, in order to promote CAR-T cell trafficking to B cell follicles. To this end, we designed constructs for expression of the CARs, without or with co-expression of CXCR5. CAR-transduced T cells were analyzed using both an in vitro transwell assay of chemokine-directed cell migration and a novel ex vivo B cell follicle migration assay. In addition, we tested the ability of T cells expressing CAR and CXCR5 to suppress viral replication in vitro.

\section{CAR and CXCR5 Expression in Transduced Primary Rhesus Macaque T Cells}

For this study, we developed gammaretroviral vectors encoding the rhCD4-MBL CAR and rhCXCR5, and vectors encoding bicistronic constructs to express both proteins. We developed two variations of bicistronic vectors, one with CXCR5 coexpression driven by an internal ribosome entry site (IRES) and the other via a P2A self-cleavage site (70). For simplicity, the constructs encoding the rhCD4-MBL CAR alone or the bicistronic rhCD4-MBL CAR plus rhCXCR5 are, respectively, referred to as CAR or CAR/CXCR5; for the latter, the use of either the IRES or $\mathrm{P} 2 \mathrm{~A}$ modalities is indicated. The constructs are shown schematically in Figure 1A.

In Figures 1B-F, T cells derived from activated rhesus PBMCs were transduced with gammaretroviral vectors encoding the CAR or CXCR5 genes alone, or the bicistronic CAR/CXCR5 constructs (IRES or P2A). Cell viabilities posttransduction were 87-90\% (data not shown). Antibodies directed against MBL or CXCR5 were used to detect surface expression of the CAR and CXCR5, respectively. Transduction with the CAR (Figure 1B) or CXCR5 (Figure 1C) vectors gave the expected surface expression of the corresponding individual proteins. For vectors encoding the bicistronic CAR/CXCR5, the P2A-based construct yielded a clear population of cells expressing both CAR and CXCR5, with only a small fraction of cells expressing only one of the proteins; by contrast, the IRES-based construct appeared less effective at co-expressing CXCR5 relative to CAR, since the fraction of cells expressing only the CAR was comparable to that expressing both proteins, with a minimal fraction expressing only CXCR5 only (Figures 1D,E). These results are consistent with the efficient P2A system producing equivalent amounts of the two post-cleavage components of a bicistronic construct, as contrasted with the relatively inefficient expression of the downstream component in the IRES system $(75,76)$. Moreover, as indicated in Figure 1G, the P2A-based construct produced cells with nearly twofold higher surface expression levels of CXCR5 than obtained with the IRESbased construct (median 1.8-fold higher; range 1.4- to 2.2-fold).

The percentages of $\mathrm{T}$ cells that expressed the CAR and CXCR5 with each construct are shown in Figure 1H. Transduction with the vectors encoding CAR-only or CXCR5-only yielded a median of $44.4 \%$ (range $40-47.6 \%$ ) and $81.1 \%$ (range $51.8-84.2 \%$ ) of cells expressing each protein, respectively. Cells transduced with the IRES-based bicistronic CAR/CXCR5 vector showed higher number of cells expressing the CAR compared to CXCR5, with a median cell expression of $37.2 \%$ (range 5.6-50.2\%) for the CAR and $19.4 \%$ (range 4.7-19.7\%) for CXCR5. In contrast, cells transduced with the P2A-based CAR/CXCR5 vector showed similar expression of the two proteins, with a median of $40.2 \%$ (range 37.3-52.2\%) for the CAR and 38.9\% (range 27.5-50.2\%) for CXCR5. Similar transduction efficiencies were found with enriched rhesus CD8 T cells transduced with these vectors (data not shown). The percentage of cells that co-expressed CAR and CXCR5 is shown in Figure 1I. Cells transduced with the IRES-based construct showed a median co-expression efficiency of $18.1 \%$ (range $4.3-18.9 \%$ ), whereas cells transduced with the P2A-based construct resulted in a significantly higher coexpression efficiency of 33.3\% (range of 25.9-38.3). Thus, the data in Figure 1 establish the suitability of the P2A-based bicistronic system for efficient co-expression of CAR and the B cell folliclehoming chemokine receptor CXCR5, and its superiority over the IRES-based system. 
A

CAR

Cि4

\begin{tabular}{|l|l|}
\hline MBL-NMN CD28 & CD3 $\zeta$ \\
\hline
\end{tabular}

\section{CXCR5}

CXCR5

CAR/CXCR5 with IRES

CD4- MBL-NMW CD28 $\mathrm{CD} \zeta$ IRES - CXCR5

CAR/CXCR5 with P2A

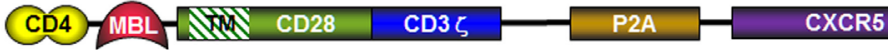

B

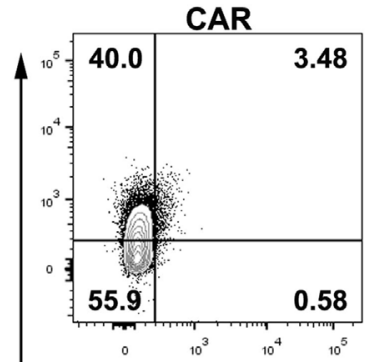

D

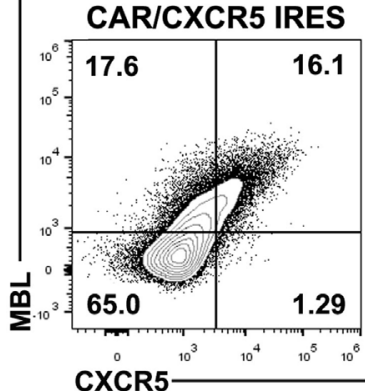

C CXCR5

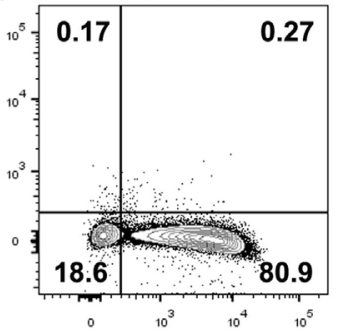

E

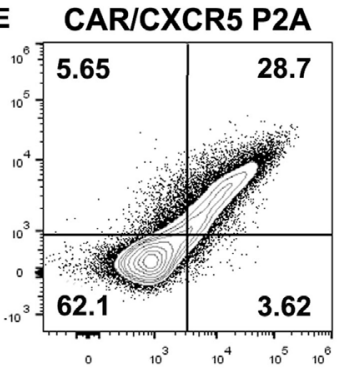

G

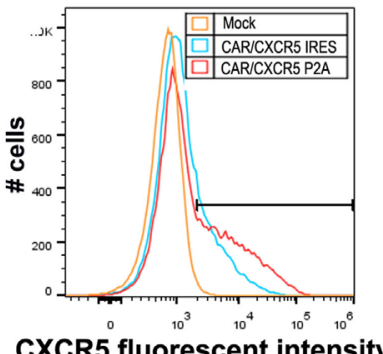

H

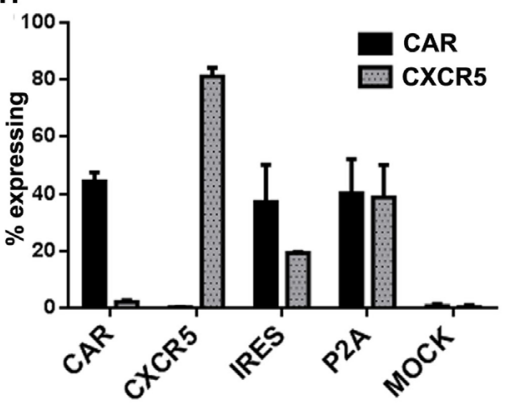

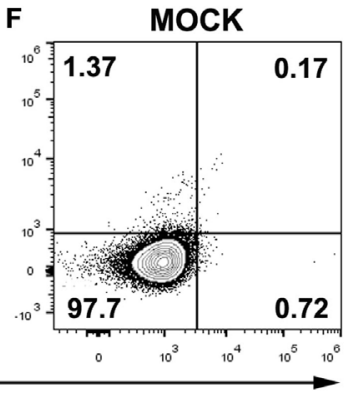

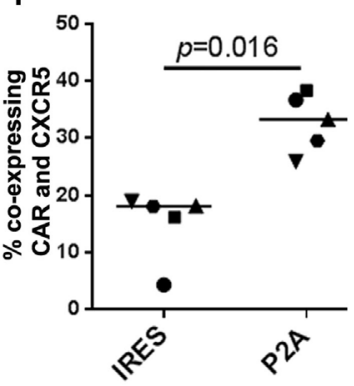

Transduction vector

FIGURE 1 | Construct design, and expression in rhesus macaque T cells. (A) Schematic figures showing constructs encoding the chimeric antigen receptor (CAR) (rhCD4-MBL CAR), rhCXCR5, and the bicistronic CAR/CXCR5 encoding both proteins, with CXCR5 expression mediated by IRES or P2A. In all cases, the targeting domains are linked to domains from rhesus CD28 including a short extracellular hinge, transmembrane TM, and cytoplasmic signaling, followed by the CD3 activation domain. Cells were transduced with gammaretroviral vectors encoding (B) CAR, (C) CXCR5, (D) CAR/CXCR5 (IRES), (E) CAR/CXCR5 (P2A), or (F) mock-transfected, and analyzed by flow cytometry. Cells were pre-gated sequentially on lymphocytes, singlets, live cells, and CD3+ cells ( $T$ cells) and evaluated for CAR and CXCR5 expression, using antibodies against mannose binding lectin (MBL) and CXCR5, respectively. (G) Histogram depicting fluoroscent intensites of CXCR5 expression from samples shown in panels (D-F). (H) Median percentage of T cells that expressed the CAR and CXCR5 in activated PBMCs transduced with CAR ( $n=3)$, CXCR5 $(n=3)$, CAR/CXCR5 (IRES) $(n=5)$, CAR/CXCR5 (P2A) $(n=5)$ and mock-transduced $(n=5)$. (I) The percentage of T cells that coexpressed the CAR and CXCR5 in activated PBMCs transduced with either CAR/CXCR5 (IRES) or CAR/CXCR5 (P2A). 


\section{CXCR5 Co-Expression Promotes CAR-T Cell Migration Selectively to CXCL13 In Vitro}

We next tested the ability of CXCR5 co-expression to promote migration of CAR-T cells toward CXCL13, the chemokine ligand for CXCR5. To this end, we utilized an in vitro transwell migration assay. Using this assay, we found that both CAR-transduced and CAR/CXCR5-transduced PBMCs similarly migrated toward a positive control chemokine CXCL12 (SDF-1 $\alpha)$ that is strongly chemotactic for lymphocytes (77) demonstrating the ability of both CAR and CAR/CXCR5-transduced cells to migrate to a chemotactic stimulus (Figure 2A). In contrast, significantly more CAR/CXCR5-transduced than CAR-transduced PBMCs migrated toward CXCL13 (Figure 2B). Furthermore, increasing specific migration to CXCL13 was seen with an increase in the percentage of cells expressing CXCR5 (Figure 2C). For these studies, a median of $54 \%$ (range 12-64\%) of CAR/CXCR5-transduced cells expressed CXCR5. By contrast, a median of only $2 \%$ (range $1-5 \%$ ) of the CAR-transduced cells expressed CXCR5 and they showed minimal migration to the stimulus. These results demonstrate that co-expression of CXCR5 promotes selective migration of the CAR-T cells toward CXCL13 in vitro.

\section{CAR/CXCR5-Transduced CD8 ${ }^{+}$T Cells Selectively Migrate into B Cell Follicles Ex Vivo}

As an additional means to evaluate the ability of CXCR5 to promote selective migration of CAR-T cells, we developed a novel ex vivo B cell follicle migration assay. This method was adapted from previously described ex vivo live tissue migration assays that tracked $\mathrm{T}$ cells in mouse thymus tissue using twophoton microscopy $(78,79)$. For these studies, we evaluated the migration of CTV-labeled CAR- and CAR/CXCR5-transduced primary rhesus macaque $\mathrm{CD} 8^{+} \mathrm{T}$ cells in fresh lymph node tissue sections. Figure $\mathbf{3 A}$ shows representative images of sections incubated with CTV-labeled CAR and CAR/CXCR5transduced cells. Similar levels of total $\mathrm{CTV}^{+}$cells were detected in lymph node sections incubated with CAR versus CAR/ CXCR5-transduced cells (Figure 3B). While total numbers of cells were similar, significant differences were observed in the levels of CAR- compared to CAR/CXCR5-transduced cells in follicular and extrafollicular compartments. Significantly lower levels of $\mathrm{CTV}^{+}$cells were found in follicular compared to extrafollicular areas in sections incubated with CAR-transduced cells (Figure 3C). In contrast, significantly higher levels of $\mathrm{CTV}^{+}$cells were found in follicular compared to extrafollicular areas in sections incubated with CAR/CXCR5-transduced cells (Figure 3D). As a result, significantly large increases in the follicular to extrafollicular ratios (F:EF) of CTV-labeled cells were detected in the tissue sections incubated with CAR/CXCR5compared to CAR-transduced T cells. Sections incubated with CAR/CXCR5-transduced cells showed a median F:EF ratio of 2.8 (range of 1.5-6.9), whereas sections incubated with CARtransduced T cells showed a median ratio of 0.4 (range $0.3-0.7$ ) (Figure 3E). An increased follicular to extrafollicular ratio was seen with an increase in the percentage of cells expressing CXCR5 (Figure 3F). A median of 46\% (range 23-71\%) of CAR/ CXCR5-transduced cells expressed CXCR5 and they showed relatively high F:EF ratios. By contrast, a median of only $1.6 \%$ (range $0.2-4.1 \%$ ) of the CAR-transduced cells expressed CXCR5 and they showed correspondingly low F:EF ratios. Thus, in this novel ex vivo B cell follicle migration assay, CAR/CXCR5- but not CAR-transduced $\mathrm{CD}^{+} \mathrm{T}$ cells preferentially migrated to B cell follicles.

\section{CXCR5 Co-Expression Does Not Impair CAR-T Cell-Mediated Suppression of SIV Replication In Vitro}

The all-rhesus CD4-MBL CAR (rhCD4-MBL) displayed potent suppression of multiple SIV strains (Hajduczki et al., manuscript in preparation). For this study, we tested whether co-expression of CXCR5 affected the potency of SIV suppression by $\mathrm{T}$ cells expressing the rhesus CD4-MBL CAR. PBMCs transduced with the CAR or CAR/CXCR5 vectors, were cocultured with rhesus PBMC targets infected with two different pathogenic SIV
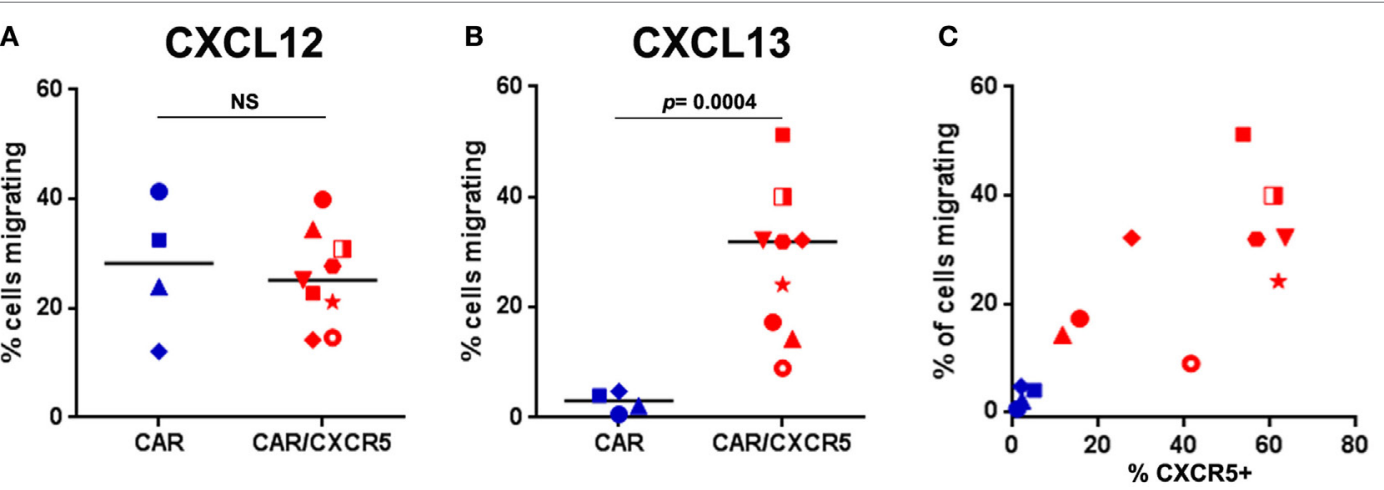

FIGURE 2 | Co-expression of CXCR5 promotes selective migration of chimeric antigen receptor (CAR)-T cells toward CXCL13 in vitro. The percentage of CARor CAR/CXCR5-transduced PBMC that migrated toward (A) CXCL12 (SDF-1) or (B) CXCL13 was measured in transwell plates. (C) The relationship between the percentage of cells expressing CXCR5 and the percentage of cells that migrated. In all panels, each data point symbol represents the mean value of duplicate samples obtained with cells from individual animals, with colors indicating transduction with CAR (blue) or CAR/CXCR5 (red). 

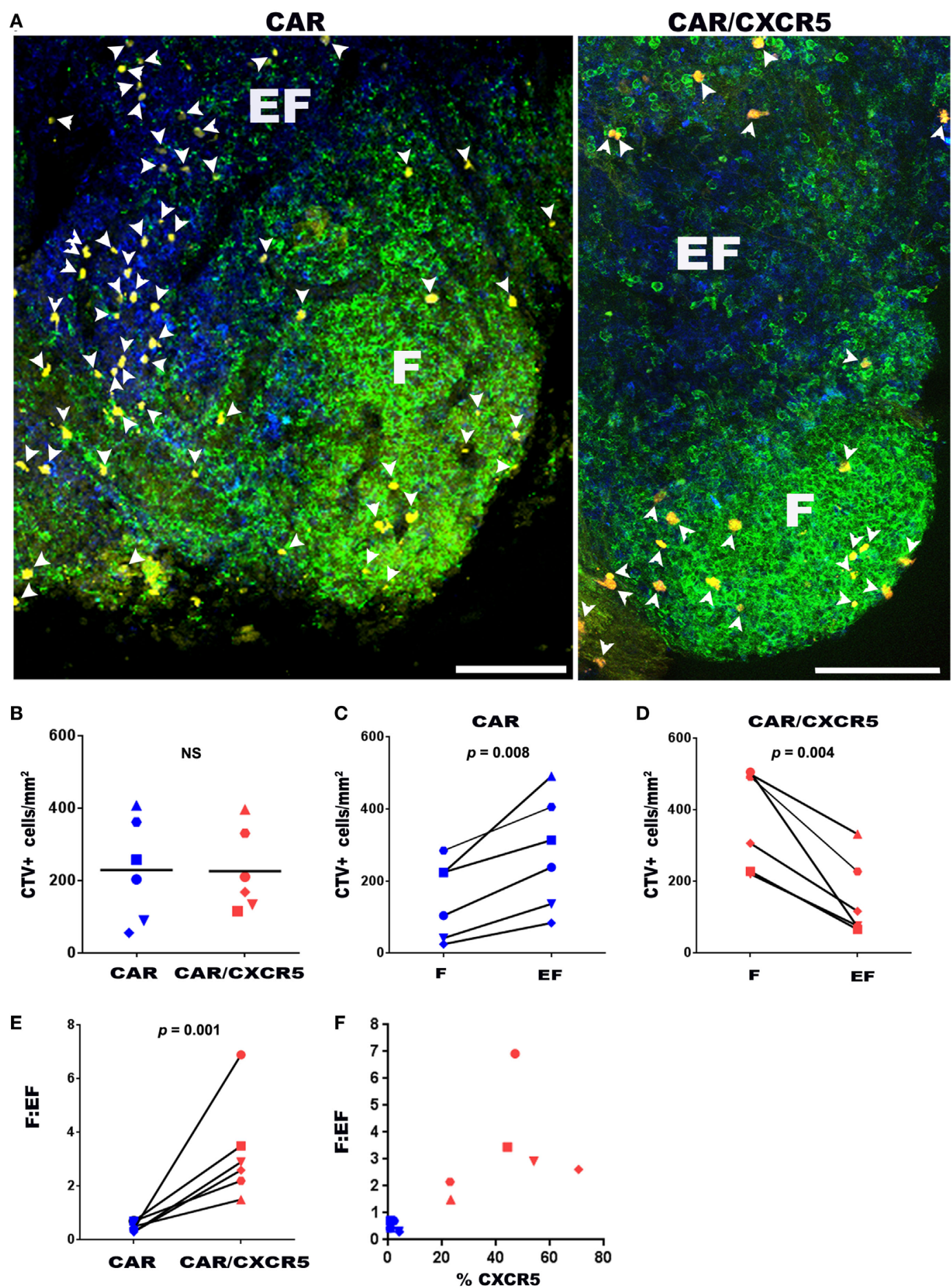

FIGURE 3 | CXCR5 co-expression enhances CD8 ${ }^{+}$CAR-T cell migration to B cell follicles ex vivo. (A) Chimeric antigen receptor (CAR) or CAR/CXCR5-transduced rhesus macaque $\mathrm{CD}^{+} \mathrm{T}$ cells were stained with cell trace violet dye (CTV) (pseudo-colored yellow), then pipetted on to fresh rhesus macaque lymph node sections and incubated for $6 \mathrm{~h}$ at $37^{\circ} \mathrm{C}$. Sections were then fixed and stained with anti-CD20 antibodies (green) to delineate B cell follicles (F) and anti-CD3 antibodies (blue) to delineate the $\mathrm{T}$ cell zone and extrafollicular areas (EF). Arrowheads indicate CTV ${ }^{+}$cells. Confocal images were collected with a 20x objective. Scale bars equal $100 \mu \mathrm{m}$. (B) Similar total levels of CFSE-labeled CD8 ${ }^{+}$T cells were detected in tissues incubated with CAR- and CAR/CXCR5- transduced cells. (C) CARtransduced cells showed higher levels in the extrafollicular regions than in the follicles. (D) By contrast, CAR/CXCR5-transduced cells showed increased levels within B cell follicles. (E) CAR/CXCR5-transduced cells showed higher F:EF ratios compared to CAR-transduced cells. (F) The relationship between the percentage of transduced cells that expressed CXCR5 and F:EF ratios. Each symbol represents individual animals from which CD8 ${ }^{+} \mathrm{T}$ cells were derived. 
isolates, $\mathrm{SIV}_{\text {mac239 }}$ and $\mathrm{SIV}_{\mathrm{E} 660 \text {. The negative controls employed }}$ included adding no effector $\mathrm{T}$ cells, and adding effector $\mathrm{T}$ cells that were transduced with the 139 CAR that recognizes an irrelevant epitope [a glioma-specific variant of the epidermal growth factor receptor (80)]. Robust spreading of viral infection by both SIV strains was evident in the presence of the negative control effector cells (no effector $\mathrm{T}$ cells and 139 CAR-transduced $\mathrm{T}$ cells). In contrast, CAR-transduced and CAR/CXCR5transduced effectors suppressed infection by both strains with equivalent high potency over the 12-day infection, at $\mathrm{E}: \mathrm{T}$ ratios of $1: 1$ or $0.2: 1$ (Figure 4). These data demonstrate that the antiviral activity of CAR-T cells is not altered by co-expression of the CXCR5 follicular trafficking chemokine receptor on the effector cell surface.

\section{DISCUSSION}

In most HIV-infected individuals and SIV-infected rhesus macaques, virus-specific CTL fail to accumulate to high levels in $\mathrm{B}$ cell follicles $(8,9,40-42)$, where virus replication is most concentrated prior to the development of AIDS (7-12). The paucity of virus-specific CTL in follicles permit ongoing replication $(8,36$, $52,54)$. We hypothesize that increasing levels of virus-specific CTL in follicles will lead to better control of viral replication and may lead to long-term durable remission in the absence of ART, i.e., a "functional cure." In this study, we developed tools to test this hypothesis in the SIV-infected rhesus macaque model of HIV infection. To this end, we developed gammaretroviral vectors for co-expression of a potent bispecific anti-SIV CAR (rhCD4-MBL) and the B cell follicle-homing chemokine receptor CXCR5.

Our initial bicistronic constructs encoding both the CAR and CXCR5 utilized an internal ribosome entry site (IRES) to achieve co-expression. We found inconsistent and often low levels of cells that co-expressed both the CAR and CXCR5. This was likely due to inefficient initiation of translation at the IRES. This finding was not altogether surprising as it is well known that IRES-dependent gene expression from a bicistronic construct is not always efficient in all cell systems $(75,76)$. To achieve more consistent levels of CAR and CXCR5 co-expression, we tested an alternative construct with the porcine teschovirus-1 P2A self-cleavage site between the CAR and CXCR5 genes. The P2A-sequence allows the cell to produce both proteins without re-initiation of translation due to a "stop and go" translational effect mediated by the ribosome, thereby resulting in similar levels of expression of the two proteins $(70,81)$. In contrast with the IRES-based CAR/CXCR5 construct, T cells transduced with the P2A-based construct consistently produced efficient co-expression of both proteins on the T cell surface. Moreover, the P2A yielded nearly twofold higher levels of CXCR5 at the cell surface. These results highlight the superiority of the P2A compared to the IRES modality for advancing the CAR/CXCR5 system as an immunotherapy product.

Using the P2A system, we demonstrated CXCR5 functionality in promoting targeted migration of CAR-T cells. In an in vitro migration assay, CXCR5 co-expression drove selective migration of rhesus CAR-T cells toward CXCL13, the chemokine ligand for CXCR5 responsible for follicular homing. Moreover, using in a novel ex vivo B cell follicle migration assay, we demonstrated that CXCR5 co-expression promoted accumulation of rhesus CAR-T cells in B cell follicles of rhesus lymphoid tissue. This finding is supported by the recent report showing that rhesus $\mathrm{CD}^{+} \mathrm{T}$ cells engineered to express human CXCR5 and infused into rhesus macaques accumulated within $\mathrm{B}$ cell follicles in vivo (82). The T cells used in that study, however, did not contain a

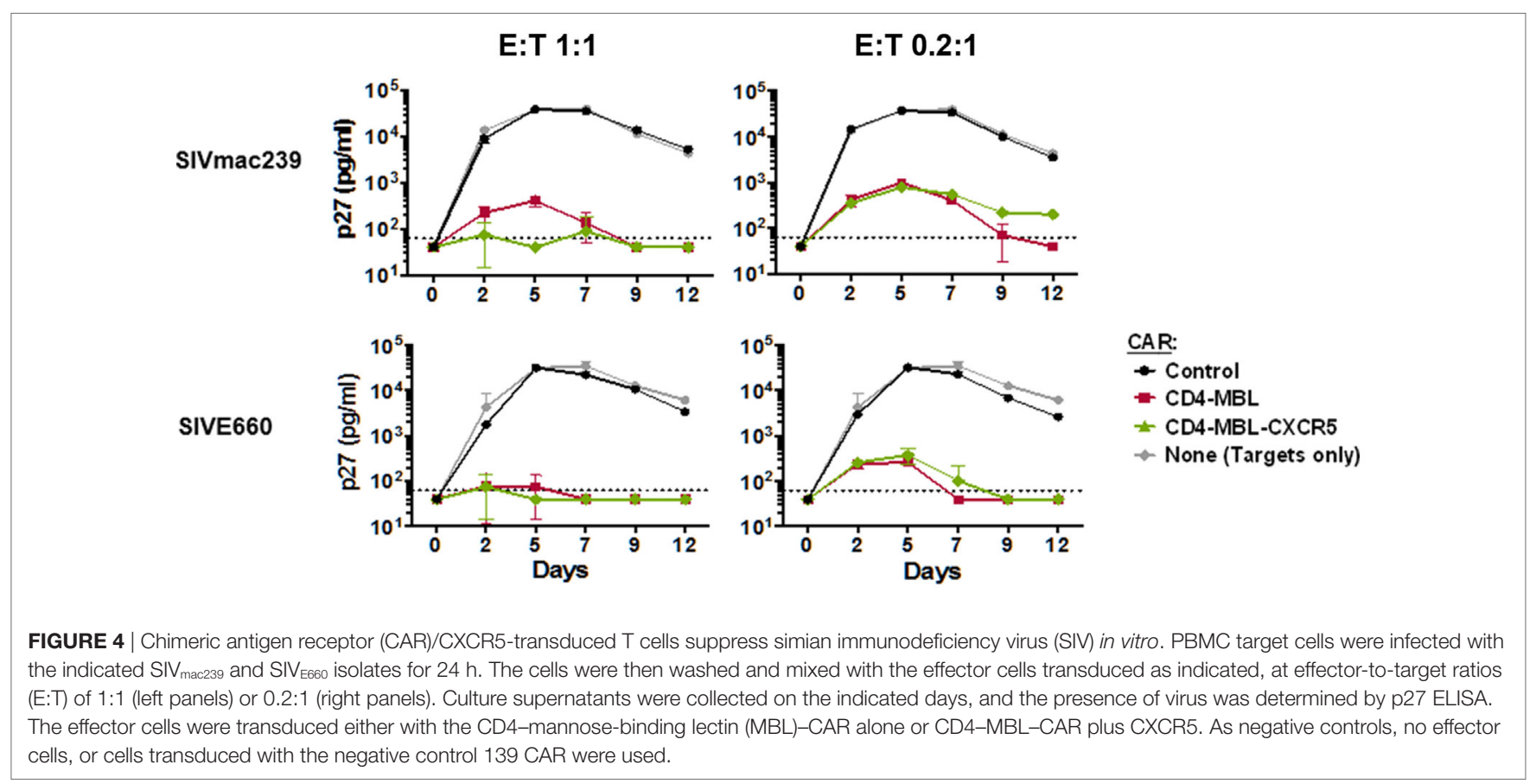


viral-targeting CAR or other antiviral moiety required for suppressing virus replication.

We previously demonstrated that human CD4-MBL CAR-T cells are capable of potently suppressing in vitro replication of genetically diverse HIV-1 isolates (68). The rhesus variant of this CAR displays potent suppressive activity against multiple SIV strains (Hajduczki et al., in preparation). Here, we show that co-expression of rhesus CXCR5 causes no impairment of the SIV-suppressive activity of this CAR.

As mentioned, we hypothesize that treatment with autologous CAR/CXCR5-transduced $\mathrm{T}$ cells can be a valuable component for achieving sustained remission of HIV. Future studies to evaluate the in vivo efficacy of CAR/CXCR5 immunotherapy must address multiple complexities under active study in the cancer field $(56,83,84)$, plus others distinct for $\operatorname{HIV}(60,85,86)$. Robust proliferation and persistence of the adoptively transferred cells is especially critical for the long-term (life-long?) viral suppression required for an HIV functional cure. Diverse aspects are being investigated, including choice of optimal cell type ( $T$ cells early stages of differentiation, hematopoietic stem cells, etc.), mode of ex vivo cell expansion, requirements for CAR expression on both $\mathrm{CD}^{+}$and $\mathrm{CD} 8^{+} \mathrm{T}$ cells, alternative methods for CAR gene introduction (viral vector transduction, targeted gene insertion), influence of alternative co-stimulatory domains (CD28, 4-1BB, etc.), and strategies to limit CAR-T cell exhaustion.

Additional challenges confront CAR-based immunotherapy against HIV. A particular concern involves the potential for the CAR-T cells to become infected, which would likely compromise their function and persistence. The bispecific CD4-based CARs such as CD4-MBL $(67,68)$ are advantageous in that the second moiety prevents the CD4 from acting as an HIV entry receptor on CAR-expressing $\mathrm{CD}^{+} \mathrm{T}$ cells; however, an additional mode of protection is required for CAR-expressing $\mathrm{CD} 4{ }^{+} \mathrm{T}$ cells, which are susceptible to infection via the endogenous CD4 molecules. Another issue is the requirement for antigenic stimulation to maintain the CAR-T cells. Within the B cell follicle, infected Tfh cells may provide the necessary stimulatory activity. If CAR-T cells are administered after effective HIV suppression with ART, the required antigenic stimulation presumably would occur upon drug cessation. For maintenance of CAR-mediated suppression in the absence of ART, the spontaneous activation of latently infected cells may provide the necessary antigenic stimulation. Well-designed studies in suitable animal models will help pave the way toward efficacious CAR-T cell therapy as a component of an HIV functional cure.

\section{ETHICS STATEMENT}

Indian-derived rhesus macaque monkeys (Macacca mulatta) described in this study were housed at the Wisconsin National Primate Reasearch Center in accordance with the regulations of the American Association of Accreditation of Laboratory Animal Care and the standards of the Association for Assessment and Accreditation of Laboratory Animal Care International. All protocols and procedures were approved by the relevant
Institutional Animal Care and Use Committee at the University of Wisconsin-Madison. All animals were housed indoors in an SOP-driven, AAALAC-accredited facility. Husbandry and care met the guidance of the Animal Welfare Regulations, OLAW reporting and the standards set forth in The Guide for the Care and Use of Laboratory Animals.

\section{AUTHOR CONTRIBUTIONS}

$\mathrm{KH}$ assisted with vector construction, performed transduction experiments, performed the in vitro migration assays, and assisted with drafting this manuscript; $\mathrm{AH}$ performed the viral suppression assays and assisted with drafting of this manuscript, MP optimized protocols, oversaw and performed virus production and transduction experiments in the Skinner lab, assisted with subcloning genes and sequencing vectors, and drafted this manuscript; GM developed and performed the ex vivo migration assays; DV-I constructed and characterized CAR constructs; ER provided study oversight, assisted with flow cytometry, and oversaw acquisition and isolation of primate cells; EC provided study oversight, obtained funding, and assisted with drafting this manuscript; EB oversaw all aspects of CAR design and functional characterization viral suppression assays, obtained funding, and contributed to drafting this manuscript; PS conceived of the studies, obtained funding, provided study oversight, and drafted this manuscript.

\section{ACKNOWLEDGMENTS}

The authors thank Ms. Chi Phan at the University of Minnesota, and Dr. Martin Wohlfart at the Fred Hutch Viral Vector Core for assistance with viral production, Ms. Kim Weisgrau at the University of Wisconsin-Madison for isolating PBMCs and enriching $\mathrm{CD}^{+} \mathrm{T}$ cells, Dr. Virgilio Bundoc at NIAID for technical support with the CAR-mediated virus suppression assays, and Dr. Brian Fife at the University of Minnesota for assistance in developing the ex vivo migration assay. The authors also thank Dr. Geoff Hart at the University of Minnesota for assistance with flow cytometry, Dr. Aaron Rendahl at the University of Minnesota for assistance with statistical analysis, Dr. David N. Levy at New York University for technical guidance, and Dr. Matthew Bronnimann and Ms. Joy Folkvord at the University of Arizona for critical review of this manuscript. Anti-CD3 and anti-CD28 used in these studies were provided by the NIH Nonhuman Primate Reagent Resource (R24 OD010976, U24 AI126683).

\section{FUNDING}

This study was supported by NIH grants 5R01AI096966-06S1 (PS, EC, and EB), 1UM1AI26617 (PS, EC, and EB), P51OD011106/ P51RR000167 (ER), MN-REACH grant 5U01HL127479-03 (PS), and NIH-T32 DA007097 (GM), as well as by funds provided by the NIAID Division of Intramural Research and the NIH Intramural AIDS Targeted Antiviral Program. 


\section{REFERENCES}

1. UNAIDS. Global AIDS Update 2016. (2016). Available from: http://www. unaids.org/sites/default/files/media_asset/global-AIDS-update-2016_en.pdf

2. Triant VA, Josephson F, Rochester CG, Althoff KN, Marcus K, Munk R, et al. Adverse outcome analyses of observational data: assessing cardiovascular risk in HIV disease. Clin Infect Dis (2012) 54(3):408-13. doi:10.1093/cid/cir829

3. Mothobi NZ, Brew BJ. Neurocognitive dysfunction in the highly active antiretroviral therapy era. Curr Opin Infect Dis (2012) 25(1):4-9. doi:10.1097/ QCO.0b013e32834ef586

4. Deeken JF, Tjen-A-Looi A, Rudek MA, Okuliar C, Young M, Little RF, et al. The rising challenge of non-AIDS-defining cancers in HIV-infected patients. Clin Infect Dis (2012) 55(9):1228-35. doi:10.1093/cid/cis613

5. Harrison K, Song R, Zhang X. Life expectancy after HIV diagnosis based on national HIV surveillance data from 25 states, United States. J Acquir Immune Defic Syndr (2010) 53(1):124-30. doi:10.1097/QAI.0b013e3181b563e7

6. Deeks SG, Lewin SR, Ross AL, Ananworanich J, Benkirane M, Cannon P, et al. International AIDS Society global scientific strategy: towards an HIV cure 2016. Nat Med (2016) 22(8):839-50. doi:10.1038/nm.4108

7. Folkvord JM, Armon C, Connick E. Lymphoid follicles are sites of heightened human immunodeficiency virus type 1 (HIV-1) replication and reduced antiretroviral effector mechanisms. AIDS Res Hum Retroviruses (2005) 21(5):363-70. doi:10.1089/aid.2005.21.363

8. Connick E, Folkvord JM, Lind KT, Rakasz EG, Miles B, Wilson NA, et al. Compartmentalization of simian immunodeficiency virus replication within secondary lymphoid tissues of rhesus macaques is linked to disease stage and inversely related to localization of virus-specific CTL. J Immunol (2014) 193(11):5613-25. doi:10.4049/jimmunol.1401161

9. Connick E, Mattila T, Folkvord JM, Schlichtemeier R, Meditz AL, Ray MG, et al. CTL fail to accumulate at sites of HIV-1 replication in lymphoid tissue. J Immunol (2007) 178(11):6975-83. doi:10.4049/jimmunol.178.11.6975

10. Hufert FT, van Lunzen J, Janossy G, Bertram S, Schmitz J, Haller O, et al. Germinal centre CD4+ T cells are an important site of HIV replication in vivo. AIDS (1997) 11(7):849-57. doi:10.1097/00002030-199707000-00003

11. Tenner-RaczK, StellbrinkHJ, vanLunzen J, Schneider C, Jacobs JP, RaschdorffB, et al. The unenlarged lymph nodes of HIV-1-infected, asymptomatic patients with high CD4 $\mathrm{T}$ cell counts are sites for virus replication and CD4 T cell proliferation. The impact of highly active antiretroviral therapy. J Exp Med (1998) 187(6):949-59. doi:10.1084/jem.187.6.949

12. Biberfeld P, Chayt KJ, Marselle LM, Biberfeld G, Gallo RC, Harper ME. HTLV-III expression in infected lymph nodes and relevance to pathogenesis of lymphadenopathy. Am J Pathol (1986) 125(3):436-42.

13. Perreau M, Savoye AL, De Crignis E, Corpataux JM, Cubas R, Haddad EK, et al. Follicular helper T cells serve as the major CD4 T cell compartment for HIV-1 infection, replication, and production. J Exp Med (2013) 210(1): 143-56. doi:10.1084/jem.20121932

14. Brenchley JM, Vinton C, Tabb B, Hao XP, Connick E, Paiardini M, et al. Differential infection patterns of CD4+ $\mathrm{T}$ cells and lymphoid tissue viral burden distinguish progressive and nonprogressive lentiviral infections. Blood (2012) 120(20):4172-81. doi:10.1182/blood-2012-06-437608

15. Embretson J, Zupancic M, Ribas JL, Burke A, Racz P, Tenner-Racz K, et al. Massive covert infection of helper T lymphocytes and macrophages by HIV during the incubation period of AIDS. Nature (1993) 362(6418):359-62. doi:10.1038/362359a0

16. Pantaleo G, Graziosi C, Demarest JF, Butini L, Montroni M, Fox CH, et al. $\mathrm{HIV}$ infection is active and progressive in lymphoid tissue during the clinically latent stage of disease. Nature (1993) 362(6418):355-8. doi:10.1038/362355a0

17. Heath SL, Tew JG, Tew JG, Szakal AK, Burton GF. Follicular dendritic cells and human immunodeficiency virus infectivity. Nature (1995) 377(6551): 740-4. doi:10.1038/377740a0

18. Joling P, Bakker LJ, Van Strijp JA, Meerloo T, de Graaf L, Dekker ME, et al. Binding of human immunodeficiency virus type-1 to follicular dendritic cells in vitro is complement dependent. J Immunol (1993) 150(3):1065-73.

19. Smith-Franklin BA, Keele BF, Tew JG, Gartner S, Szakal AK, Estes JD, et al. Follicular dendritic cells and the persistence of HIV infectivity: the role of antibodies and Fcgamma receptors. JImmunol (2002) 168(5):2408-14. doi:10.4049/jimmunol.168.5.2408
20. Walker B, McMichael A. The T-cell response to HIV. Cold Spring Harb Perspect Med (2012) 2(11):1-19. doi:10.1101/cshperspect.a007054

21. Goulder PJR, Watkins DI. HIV and SIV CTL escape: implications for vaccine design. Nat Rev Immunol (2004) 4(8):630-40. doi:10.1038/nri1417

22. O'Connor DH, Allen TM, Vogel TU, Jing P, DeSouza IP, Dodds E, et al. Acute phase cytotoxic $\mathrm{T}$ lymphocyte escape is a hallmark of simian immunodeficiency virus infection. Nat Med (2002) 8(5):493-9. doi:10.1038/nm0502-493

23. Allen TM, O'Connor DH, Jing P, Dzuris JL, Mothé BR, Vogel TU, et al. Tatspecific cytotoxic T lymphocytes select for SIV escape variants during resolution of primary viraemia. Nature (2000) 407(6802):386-90. doi:10.1038/35030124

24. Mothé BR, Horton H, Carter DK, Allen TM, Liebl ME, Skinner P, et al. Dominance of CD8 responses specific for epitopes bound by a single major histocompatibility complex class I molecule during the acute phase of viral infection. J Virol (2002) 76(2):875-84. doi:10.1128/JVI.76.2.875-884.2002

25. Goulder PJ, Brander C, Tang Y, Tremblay C, Colbert RA, Addo MM, et al. Evolution and transmission of stable CTL escape mutations in HIV infection. Nature (2001) 412(6844):334-8. doi:10.1038/35085576

26. Liu Y, McNevin JP, Holte S, McElrath MJ, Mullins JI. Dynamics of viral evolution and CTL responses in HIV-1 infection. PLoS One (2011) 6(1):e15639. doi:10.1371/journal.pone.0015639

27. Moore CB. Evidence of HIV-1 adaptation to HLA-restricted immune responses at a population level. Science (2002) 296(5572):1439-43. doi:10.1126/science. 1069660

28. Deng K, Pertea M, Rongvaux A, Wang L, Durand CM, Ghiaur G, et al. Broad CTL response is required to clear latent HIV-1 due to dominance of escape mutations. Nature (2015) 517(7534):381-5. doi:10.1038/nature14053

29. Schwartz O, Maréchal V, Le Gall S, Lemonnier F, Heard JM. Endocytosis of major histocompatibility complex class I molecules is induced by the HIV-1 Nef protein. Nat Med (1996) 2(3):338-42. doi:10.1038/nm0396-338

30. Collins KL, Chen BK, Kalams SA, Walker BD, Baltimore D. HIV-1 Nef protein protects infected primary cells against killing by cytotoxic T lymphocytes. Nature (1998) 391(6665):397-401. doi:10.1038/34929

31. Zack JA, Arrigo SJ, Weitsman SR, Go AS, Haislip A, Chen ISY. HIV-1 entry into quiescent primary lymphocytes: molecular analysis reveals a labile, latent viral structure. Cell (1990) 61(2):213-22. doi:10.1016/0092-8674(90) 90802-L

32. Day CL, Kaufmann DE, Kiepiela P, Brown JA, Moodley ES, Reddy S, et al. PD-1 expression on HIV-specific T cells is associated with T-cell exhaustion and disease progression. Nature (2006) 443(7109):350-4. doi:10.1038/ nature 05115

33. Xiong Y, Luscher MA, Altman JD, Hulsey M, Robinson HL, Ostrowski M, et al. Simian immunodeficiency virus (SIV) infection of a rhesus macaque induces SIV-specific CD8(+) T cells with a defect in effector function that is reversible on extended interleukin-2 incubation. J Virol (2001) 75(6):3028-33. doi:10.1128/JVI.75.6.3028-3033.2001

34. Vogel TU, Allen TM, Altman JD, Watkins DI. Functional impairment of simian immunodeficiency virus-specific CD8+ T cells during the chronic phase of infection. J Virol (2001) 75(5):2458-61. doi:10.1128/JVI.75.5.2458-2461. 2001

35. Elahi S, Dinges WL, Lejarcegui N, et al. Protective HIV-specific CD8+ T cells evade Treg cell suppression. Nat Med (2011) 17(8):989-95. doi:10.1038/ nm.2422

36. Li S, Folkvord JM, Rakasz EG, Abdelaal HM, Wagstaff RK, Kovacs KJ, et al. Simian immunodeficiency virus-producing cells in follicles are partially suppressed by CD8 ${ }^{+}$cells in vivo. J Virol (2016) 90(24):11168-80. doi:10.1128/ JVI.01332-16

37. Miles B, Miller SM, Folkvord JM, Levy DN, Rakasz EG, Skinner PJ, et al. Follicular regulatory CD8 T cells impair the germinal center response in SIV and ex vivo HIV infection. PLoS Pathog (2016) 12(10):e1005924. doi:10.1371/ journal.ppat.1005924

38. Moreno-Fernandez ME, Presicce P, Chougnet CA. Homeostasis and function of regulatory T cells in HIV/SIV infection. J Virol (2012) 86(19):10262-9. doi:10.1128/JVI.00993-12

39. Estes JD, Li Q, Reynolds MR, Wietgrefe S, Duan L, Schacker T, et al. Premature induction of an immunosuppressive regulatory $\mathrm{T}$ cell response during acute simian immunodeficiency virus infection. J Infect Dis (2006) 193(5):703-12. doi: $10.1086 / 500368$ 
40. Sasikala-Appukuttan AK, Kim HO, Kinzel NJ, Hong JJ, Smith AJ, Wagstaff R, et al. Location and dynamics of the immunodominant CD8 $\mathrm{T}$ cell response to SIV $\Delta$ nef immunization and SIVmac251 vaginal challenge. PLoS One (2013) 8(12):e81623. doi:10.1371/journal.pone.0081623

41. Tjernlund A, Zhu J, Laing K, Diem K, McDonald D, Vazquez J, et al. In situ detection of Gag-specific CD8+ cells in the GI tract of SIV infected rhesus macaques. Retrovirology (2010) 7:12. doi:10.1186/1742-4690-7-12

42. Skinner P. Overcoming the immune privilege of B cell follicles to cure HIV-1 infection. J Hum Virol Retrovirol (2014) 1(1):8-10. doi:10.15406/ jhvrv.2014.01.00001

43. Förster R, Mattis AE, Kremmer E, Wolf E, Brem G, Lipp M. A putative chemokine receptor, BLR1, directs $B$ cell migration to defined lymphoid organs and specific anatomic compartments of the spleen. Cell (1996) 87(6):1037-47. doi:10.1016/S0092-8674(00)81798-5

44. Schaerli P, Willimann K, Lang AB, Lipp M, Loetscher P, Moser B. CXC chemokine receptor 5 expression defines follicular homing $\mathrm{T}$ cells with $\mathrm{B}$ cell helper function. J Exp Med (2000) 192(11):1553-62. doi:10.1084/jem.192.11.1553

45. Haynes NM, Allen CDC, Lesley R, Ansel KM, Killeen N, Cyster JG. Role of CXCR5 and CCR7 in follicular Th cell positioning and appearance of a programmed cell death gene-1high germinal center-associated subpopulation. J Immunol (2007) 179(8):5099-108. doi:10.4049/jimmunol.179.8.5099

46. Legler DF, Loetscher M, Roos RS, Clark-Lewis I, Baggiolini M, Moser B. B cell-attracting chemokine 1, a human CXC chemokine expressed in lymphoid tissues, selectively attracts B lymphocytes via BLR1/CXCR5.J Exp Med (1998) 187(4):655-60. doi:10.1084/jem.187.4.655

47. Gunn MD, Ngo VN, Ansel KM, Ekland EH, Cyster JG, Williams LT. A B-cellhoming chemokine made in lymphoid follicles activates Burkitt's lymphoma receptor-1. Nature (1998) 391(6669):799-803. doi:10.1038/35876

48. Cagigi A, Mowafi F, Phuong Dang LV, Tenner-Racz K, Atlas A, Grutzmeier S, et al. Altered expression of the receptor-ligand pair CXCR5/CXCL13 in B cells during chronic HIV-1 infection. Blood (2008) 112(12):4401-10. doi:10.1182/ blood-2008-02-140426

49. Breitfeld D, Ohl L, Kremmer E, Ellwart J, Sallusto F, Lipp M, et al. Follicular $\mathrm{B}$ helper $\mathrm{T}$ cells express CXC chemokine receptor 5 , localize to $\mathrm{B}$ cell follicles, and support immunoglobulin production. J Exp Med (2000) 192(11):1545-52. doi:10.1084/jem.192.11.1545

50. Förster R, Emrich T, Kremmer E, Lipp M. Expression of the G-protein coupled receptor BLR1 defines mature, recirculating B cells and a subset of T-helper memory cells. Blood (1994) 84(3):830-40.

51. Ansel KM, Ngo VN, Hyman PL, Luther SA, Förster R, Sedgwick JD, et al. A chemokine-driven positive feedback loop organizes lymphoid follicles. Nature (2000) 406(6793):309-14. doi:10.1038/35018581

52. He R, Hou S, Liu C, Zhang A, Bai Q, Han M, et al. Follicular CXCR5-expressing CD8+ T cells curtail chronic viral infection. Nature (2016) 537(7620):412-28. doi:10.1038/nature19317

53. Leong YA, Chen Y, Ong HS, Wu D, Man K, Deleage C, et al. CXCR5+ follicular cytotoxic T cells control viral infection in B cell follicles. Nat Immunol (2016) 17(10):1187-96. doi:10.1038/ni.3543

54. Mylvaganam GH, Rios D, Abdelaal HM, Iyer S, Tharp G, Mavinger M, et al. Dynamics of SIV-specific CXCR5+ CD8 T cells during chronic SIV infection. Proc Natl Acad Sci U S A (2017) 114(8):1976-81. doi:10.1073/ pnas. 1621418114

55. Lim WA, June $\mathrm{CH}$. The principles of engineering immune cells to treat cancer. Cell (2017) 168(4):724-40. doi:10.1016/j.cell.2017.01.016

56. Sadelain M, Rivière I, Riddell S. Therapeutic T cell engineering. Nature (2017) 545(7655):423-31. doi:10.1038/nature22395

57. KlebanoffCA, Rosenberg SA, Restifo NP. Prospects for gene-engineered T cell immunotherapy for solid cancers. Nat Med (2016) 22(1):26-36. doi:10.1038/ nm. 4015

58. Kitchen SG, Zack JA. Engineering HIV-specific immunity with chimeric antigen receptors. AIDS Patient Care STDS (2016) 30(12):556-61. doi:10.1089/ apc.2016.0239

59. Patel S, Jones RB, Nixon DF, Bollard CM. T-cell therapies for HIV: preclinical successes and current clinical strategies. Cytotherapy (2016) 18(8):931-42. doi:10.1016/j.jcyt.2016.04.007

60. Wagner TA. Combining cell and gene therapy in an effort to eradicate HIV. AIDS Patient Care STDS (2016) 30(12):534-8. doi:10.1089/apc.2016.0226
61. Riley JL, Montaner LJ. Cell-mediated immunity to target the persistent human immunodeficiency virus reservoir.J Infect Dis (2017) 215(suppl_3):S160-S171. doi:10.1093/infdis/jix002

62. Wonderlich ER, Leonard JA, Collins KL. HIV immune evasion. Disruption of antigen presentation by the HIV Nef protein. Adv Virus Res (2011) 80:103-27. doi:10.1016/B978-0-12-385987-7.00005-1

63. Scholler J, Brady TL, Binder-Scholl G, Hwang WT, Plesa G, Hege KM, et al. Decade-long safety and function of retroviral-modified chimeric antigen receptor T cells. Sci Transl Med (2012) 4(132):132ra53. doi:10.1126/ scitranslmed.3003761

64. Mitsuyasu RT, Anton PA, Deeks SG, Scadden DT, Connick E, Downs MT, et al. Prolonged survival and tissue trafficking following adoptive transfer of $\mathrm{CD} 4 \zeta$ gene-modified autologous $\mathrm{CD} 4+$ and $\mathrm{CD} 8+\mathrm{T}$ cells in human immunodeficiency virus-infected subjects. Blood (2000) 96(3):785-93.

65. Walker RE, Bechtel CM, Natarajan V, Baseler M, Hege KM, Metcalf JA, et al. Long-term in vivo survival of receptor-modified syngeneic $\mathrm{T}$ cells in patients with human immunodeficiency virus infection. Blood (2000) 96(2): 467-74.

66. Deeks SG, Wagner B, Anton PA, Mitsuyasu RT, Scadden DT, Huang C, et al. A phase II randomized study of HIV-specific T-cell gene therapy in subjects with undetectable plasma viremia on combination antiretroviral therapy. Mol Ther (2002) 5(6):788-97. doi:10.1006/mthe.2002.0611

67. Liu L, Patel B, Ghanem MH, Bundoc V, Zheng Z, Morgan RA, et al. Novel CD4-based bispecific chimeric antigen receptor designed for enhanced anti-HIV potency and absence of HIV entry receptor activity. J Virol (2015) 89(13):6685-94. doi:10.1128/JVI.00474-15

68. Ghanem MH, Bolivar-Wagers S, Dey B, Hajduczki A, Vargas-Inchaustegui DA, Danielson DT, et al. Bispecific chimeric antigen receptors targeting the CD4 binding site and high-mannose glycans of gp120 optimized for anti-HIV potency and breadth with minimal immunogenicity. Cytotherapy (2017). doi:10.1016/j.jcyt.2017.11.001

69. Hughes MS, Yu YY, Dudley ME, Zheng Z, Robbins PF, Li Y, et al. Transfer of a TCR gene derived from a patient with a marked antitumor response conveys highly active T-cell effector functions. Hum Gene Ther (2005) 16(4):457-72. doi:10.1089/hum.2005.16.457

70. Kim JH, Lee SR, Li LH, Park HJ, Park JH, Lee KY, et al. High cleavage efficiency of a 2A peptide derived from porcine teschovirus-1 in human cell lines, zebrafish and mice. PLoS One (2011) 6(4):e18556. doi:10.1371/journal. pone. 0018556

71. Delang L, Li C, Tas A, Quérat G, Albulescu IC, De Burghgraeve T, et al. The viral capping enzyme nsP1: a novel target for the inhibition of chikungunya virus infection. Sci Rep (2016) 6:31819. doi:10.1038/srep31819

72. Porter CD, Collins MK, Tailor CS, Parkar MH, Cosset FL, Weiss RA, et al. Comparison of efficiency of infection of human gene therapy target cells via four different retroviral receptors. Hum Gene Ther (1996) 7(8):913-9. doi:10.1089/hum.1996.7.8-913

73. Gori JL, Podetz-Pedersen K, Swanson D, Karlen AD, Gunther R, Somia NV, et al. Protection of mice from methotrexate toxicity by ex vivo transduction using lentivirus vectors expressing drug-resistant dihydrofolate reductase. J Pharmacol Exp Ther (2007) 322(3):989-97. doi:10.1124/jpet.107.123414

74. Abdelaal HM, Kim HO, Wagstaff R, Sawahata R, Southern PJ, Skinner PJ. Comparison of vibratome and compresstome sectioning of fresh primate lymphoid and genital tissues for in situ mhc-tetramer and immunofluorescence staining. Biol Proced Online (2015) 17(1):2. doi:10.1186/s12575-014-0012-4

75. Mizuguchi H, Xu Z, Ishii-Watabe A, Uchida E, Hayakawa T. IRES-dependent second gene expression is significantly lower than cap-dependent first gene expression in a bicistronic vector. Mol Ther (2000) 1(4):376-82. doi:10.1006/ mthe. 2000.0050

76. Ibrahimi A, Vande Velde G, Reumers V, Toelen J, Thiry I, Vandeputte C, et al. Highly efficient multicistronic lentiviral vectors with peptide $2 \mathrm{~A}$ sequences. Hum Gene Ther (2009) 20(8):845-60. doi:10.1089/hum.2008.188

77. Bleul CC, Fuhlbrigge RC, Casasnovas JM, Aiuti A, Springer TA. A highly efficacious lymphocyte chemoattractant, stromal cell-derived factor 1 (SDF-1). J Exp Med (1996) 184(3):1101-9. doi:10.1084/jem.184.3.1101

78. Melichar HJ, Ross JO, Herzmark P, Hogquist KA, Robey EA. Distinct temporal patterns of $\mathrm{T}$ cell receptor signaling during positive versus negative selection in situ. Sci Signal (2013) 6(297):ra92. doi:10.1126/scisignal.2004400 
79. Dzhagalov IL, Chen KG, Herzmark P, Robey EA. Elimination of self-reactive T cells in the thymus: a timeline for negative selection. PLoS Biol (2013) 11(5):e1001566. doi:10.1371/journal.pbio.1001566

80. Morgan RA, Johnson LA, Davis JL, Zheng Z, Woolard KD, Reap EA, et al. Recognition of glioma stem cells by genetically modified $\mathrm{T}$ cells targeting EGFRvIII and development of adoptive cell therapy for glioma. Hum Gene Ther (2012) 23(10):1043-53. doi:10.1089/hum.2012.041

81. Wang Y, Wang F, Wang R, Zhao P, Xia Q. 2A self-cleaving peptide-based multi-gene expression system in the silkworm Bombyx mori. Sci Rep (2015) 5:16273. doi:10.1038/srep16273

82. Ayala VI, Deleage C, Trivett MT, Jain S, Coren LV, Breed MW, et al. CXCR5 dependent entry of CD8 T cells into rhesus macaque B-cell follicles achieved through T-cell engineering. J Virol (2017) 91:e02507-16. doi:10.1128/ JVI.02507-16

83. Maus MV, June $\mathrm{CH}$. Making better chimeric antigen receptors for adoptive T-cell therapy. Clin Cancer Res (2016) 22(8):1875-84. doi:10.1158/1078-0432. CCR-15-1433

84. Rosenberg SA, Restifo NP. Adoptive cell transfer as personalized immunotherapy for human cancer. Science (2015) 348(6230):62-8. doi:10.1126/ science.aaa4967
85. Carrillo MA, Zhen AJ, Zack JA, Kitchen SG. New approaches for the enhancement of chimeric antigen receptors for the treatment of HIV. Transl Res (2017) 187:83-92. doi:10.1016/j.trsl.2017.07.002

86. Leibman RS, Riley JL. Engineering T cells to functionally cure HIV-1 infection. Mol Ther (2015) 23(7):1149-59. doi:10.1038/mt.2015.70

Conflict of Interest Statement: EB is co-inventor on patent applications for CD4based bispecific CARs, owned by the National Institutes of Health. PS is inventor on a provisional patent application for CAR/CXCR5 immunotherapy, owned by the University of Minnesota. All other authors declare that the research was conducted in the absence of any commercial or financial relationships that could be construed as a potential conflict of interest.

Copyright (C) 2018 Haran, Hajduczki, Pampusch, Mwakalundwa, VargasInchaustegui, Rakasz, Connick, Berger and Skinner. This is an open-access article distributed under the terms of the Creative Commons Attribution License (CC BY). The use, distribution or reproduction in other forums is permitted, provided the original author(s) and the copyright owner are credited and that the original publication in this journal is cited, in accordance with accepted academic practice. No use, distribution or reproduction is permitted which does not comply with these terms. 